\title{
COMPARISON OF APICALLY EXTRUDED DEBRIS ASSOCIATED WITH DIFFERENT NICKEL-TITANIUM SYSTEMS
}

\section{ABSTRACT}

Objectives: The aim of this study is to evaluate the influence of different instrument systems on the amount of extruded debris.

Materials and Methods: A total of 30 extracted mandibular molars with two separate canals and apical foramina in the mesial roots were selected. The root canals $(n=10)$ were randomly assigned to the six groups of file systems as follows: ProTaper Next (PTN), WaveOne (WO), WaveOne Gold (WOG), One Shape (OS), Reciproc (R) and Reciproc Blue $(\mathrm{RB})$. The extruded debris during the instrumentation was collected into Eppendorf tubes, which were weighed and then stored in an incubator at $70^{\circ} \mathrm{C}$ over a period of five days to evaporate the irrigant. After the incubation process, the Eppendorf tubes were weighed again. The difference between these two measurements, the first one before and the second one after the incubation process, was calculated. Data were statistically analyzed, and the significance level was set at $\mathrm{p}<0.05$.

Results: R produced less debris compared to WO. R and PTN files produced significantly less debris compared to the OS files $(p<0.05)$. Extruded debris in RB and WO groups were not significantly different, while RB produced less debris than WOG and OS $(\mathrm{p}<0.05)$.

Conclusions: All instrumentation systems allowed for the apical extrusion of the debris.

Keywords: Endodontics, root canal preparation, root canal therapy.

\author{
*Ahmet Keleş ${ }^{1}$ \\ (D) Emel Uzunoglu Ozyurek ${ }^{1}$ \\ (iD) Serdar Uysal ${ }^{2}$ \\ (iD)Behram Tuncel ${ }^{1}$ \\ (i) Mehmet Ozgur Uyanik ${ }^{1}$ \\ (iD) Emre Nagas ${ }^{1}$
}

ORCID IDs of the authors:

A.K. 0000-0002-7106-0006

E.U.Ö. 0000-0001-5032-9996

S.U. 0000-0001-9872-6587

B.T. 0000-0003-4372-0991

M.Ö.U. 0000-0003-3897-8314

E.N. 0000-0003-0531-3850

\footnotetext{
1 Department of Endodontics, Faculty of Dentistry, Hacettepe University, Ankara, Turkey

${ }^{2}$ Department of Dentomaxillofacial Radiology, Faculty of Dentistry, Hacettepe University, Ankara, Turkey
}

How to Cite: Keles A, Uysal S, Tuncel B, Uyanik MO, Nagas E. Comparison of Apically Extruded Debris Associated with Different Nickel-Titanium Systems. Cumhuriyet Dent J 2019;22:2:

*Corresponding Author:

Department of Endodontics, Faculty of Dentistry, Hacettepe University, Sihhiye, Ankara/Turkey, 06230

Phone: +903123052260 Fax: +903123104440 E-mail: ahmetkeles89@msn.com 


\section{INTRODUCTION}

Nickel-titanium (NiTi) rotary files have become increasingly popular among clinicians for reducing the time required to complete the instrumentation and also for minimizing the procedural errors. ${ }^{1}$ As manual files, all types of rotary or reciprocating files result in different amounts of extruded debris, which may vary according to the instrumentation technique and the design of the file systems. ${ }^{2-4}$ This may cause delayed apical healing, flare-ups, and postoperative pain. ${ }^{5}$

New types of reciprocating NiTi systems are continuously being developed, such as Waveone Gold (WOG) (Dentsply Maillefer, Ballaigues, Switzerland), and Reciproc Blue (RB) (VDW Dental, Munich, Germany), the successors of WaveOne (WO) (Dentsply Maillefer, Ballaigues, Switzerland) and Reciproc (R) (VDW Dental, Munich, Germany) systems. ${ }^{6,7}$ RB undergoes an innovative heating-cooling treatment and with this unique thermal treatment, the blue titanium oxide layer appears on the surface of the instrument. ${ }^{6}$ The WOG system is the improved version of the WO system. The cross-section of the file has been altered. ${ }^{7}$ Furthermore, the alloy is altered from MWire to gold. Gold wire technology is based on heating the file and then slowly cooling it, whereas M-Wire technology involves heat treatment before production. ${ }^{7,8}$ This thermal treatment modifies the transition temperatures, which result in superior mechanical properties and better performance of the instrument. ${ }^{6-8}$

There are limited studies evaluating the extrusion potentials of these two file systems ${ }^{9}{ }^{9-12}$ Therefore, this study was conducted to compare the amounts of apical extruded debris with either of these two novel single-file reciprocating systems, namely WOG and RB, with those of two other most commonly used single-file reciprocating systems, WO and R. A multifile system, ProtaperNext (PTN) (Dentsply Maillefer, Ballaigues, Switzerland), and a single-file system, OneShape (OS) (Micro Mega, Besançon, France), which using with continuous rotation, were used as references for comparison. The null hypothesis was that there would be no difference among these file systems in terms of the amount of the apically extruded debris.

\section{MATERIALS AND METHODS}

Thirty freshly extracted mandibular human molars with two separate canals and apical foramina in the mesial root were selected for this study after Hacettepe University non-invasive Ethics Committee approval was granted (No:GO 17/461 - 50) on May 2017. The molars with completely formed, straight roots (having a curvature of less than $10^{\circ}$ ) according to the Schneider method ${ }^{13}$, having no visible caries, fractures, calcifications, cracks or resorptions were included. Following the removal of the distal roots, the presence of the separate canals was confirmed by radiographic means obtaining the buccolingual and mesiodistal views. The tissue remnants and calculus on the root surfaces were removed. The remaining parts of the distal roots were sealed with sticky waxes in orthograde and retrograde ways. A conventional straight-line access preparation was performed. The $\# 10 \mathrm{~K}$-file was inserted into the canal until its tip was visible at the apical foramen, confirming the apical patency. The working length (WL) was set by subtracting $1 \mathrm{~mm}$ from the initial length for each canal.

\section{Debris Collection}

The process of debris collection was evaluated by a technique previously described by Myers and Montgomery. ${ }^{14}$ Stoppers were separated from Eppendorf tubes. An analytical balance (Radwag, Radom, Poland) with an accuracy of $10^{-5}$ was used to measure the pre-experimental weights of the tubes. After each tube was weighed without stoppers three times, the mean values of these measurements were calculated and noted as initial weights. A hole was made on the stoppers of each of the tubes. The teeth were inserted into the cementoenamel junction by using a 27-gauge needle (Genject, Ankara, Turkey) to balance the air pressure inside and outside the tubes. The teeth were fixed to the stoppers with cyanoacrylate. The stoppers were then attached to their Eppendorf tubes and this set-up was placed into the vials. The 30 molar teeth were randomly assigned to 6 groups of 5 specimens ( $\mathrm{n}=10$ canals/per group) in each. 
Group WOG: WaveOne GOLD (Dentsply Maillefer, Ballaigues, Switzerland) Primary (25/.07) instruments were used with "WaveOne" mode of an endodontic motor (X-Smart Plus, Dentsply Maillefer, Ballaigues, Switzerland).

Group WO: WaveOne (Dentsply Maillefer, Ballaigues, Switzerland) Primary (25/.08) instruments were used with "WaveOne" mode of the endodontic motor (X-Smart Plus).

Group R: Reciproc (VDW Dental, Munich, Germany) R25 (25/.08) instruments were used with "Reciproc" mode of the endodontic motor (X-Smart Plus).

Group RB: Reciproc Blue (VDW Dental, Munich, Germany) R25 (25/.08) instruments were used with "Reciproc" mode of the endodontic motor (X-Smart Plus).

Group OS: One Shape (Micro Mega, Besançon, France) 25.06 instruments were used with the endodontic motor (X-Smart Plus) at $350 \mathrm{rpm}$ and $2.5 \mathrm{~N} / \mathrm{cm}$.

Group PTN: ProTaper Next (Dentsply Maillefer, Ballaigues, Switzerland) instruments were used with the endodontic motor at $300 \mathrm{rpm}$ and $2 \mathrm{~N} / \mathrm{cm}$. The instrumentation sequence consisted of $\mathrm{X} 1$ (17.04) and X2 (25.06) files.

In all experimental groups, once the instrument reached to the WL and started rotating freely, it was removed. The fractured files during the process were noted. A total of $10 \mathrm{~mL}$ of distilled water was used in each canal during the preparation process to avoid any potential crystallization of sodium hypochlorite. ${ }^{15}$ After completing preparations, a final irrigation was performed with $2 \mathrm{~mL}$ distilled water. The apical parts of the teeth were washed with $1 \mathrm{~mL}$ distilled water to collect the adhered debris at the root surface. Each of the mesiobuccal (MB) and mesiolingual (ML) canals was prepared separately and the debris extruded from MB and ML roots were collected in different tubes (a total of 10 tubes per group; $n=10$ per group). The MB canal orifices were sealed with a composite material (Dentonics, Monroe, NC, USA) while instrumenting the ML canal or vice versa. Then all tubes were stored in an incubator at $70^{\circ} \mathrm{C}$ over a period of 5 days to evaporate the distilled water before weighing the extruded debris. The tubes were weighed using the same analytical balance (Radwag) to obtain the final weight of the tubes containing the extruded debris. Each tube was weighed 3 times and the mean value was calculated for each. The amount of apically extruded debris was calculated by subtracting the initial weight of tube from the final weight.

\section{Statistical Analysis}

The distribution of the data was analyzed using the Kolmogorov-Smirnov normality test. The comparisons of the amounts of extruded debris were analyzed using the one-way ANOVA and Bonferroni post-hoc tests using the SPSS 22.0 software (IBM SPSS, Chicago, IL, USA). The significance level was set at $\mathrm{p}<0.05$.

\section{RESULTS}

The mean values and standard deviations for all groups are listed in Table 1.

Table 1. Amount of extruded debris of experimental groups as mean \pm standard deviations (SD).

\begin{tabular}{lcc}
\hline File Systems* $^{*}$ & $\mathbf{N}$ & Mean \pm SD (gram) \\
Reciproc $^{\mathrm{a}}$ & 10 & $0.005 \pm 0.003$ \\
Reciproc Blue $^{\mathrm{ab}}$ & 10 & $0.007 \pm 0.001$ \\
$\mathrm{WO}^{\mathrm{bc}}$ & 10 & $0.009 \pm 0.003$ \\
$\mathrm{WOG}^{\mathrm{c}}$ & 10 & $0.011 \pm 0.003$ \\
PTN $^{\mathrm{a}}$ & 10 & $0.005 \pm 0.002$ \\
$\mathrm{OS}^{\mathrm{c}}$ & 10 & $0.013 \pm 0.004$ \\
\hline
\end{tabular}

*Different superscripts mean statistically significant difference. Significant at $\mathrm{p}<0.05$.

All instrumentation systems yielded apical extrusion materials. The lowest amount of debris was obtained in the R, RB, and PTN groups and there were no significant differences among them ( $p>0.05)$. On the other hand, WO, WOG, and OS groups extruded significantly more debris compared to the $\mathrm{R}$ and PTN Groups $(\mathrm{p}<0.05)$. Extruded debris in RB and WO groups were not significantly different, while RB produced less debris than WOG and OS $(\mathrm{p}<0.05)$. 


\section{DISCUSSION}

In this present study, different single-file reciprocating instruments were compared in terms of their apical extrusion potentials. A rotating single-file system, One Shape, and a multi-file system, ProTaper Next, were used as controls. Reciproc Blue and WaveOne Gold have been recently introduced into the dental market. Therefore, the literature review informed that there was only one published study, which evaluated the apical extrusion with RB. ${ }^{12}$ Only a limited number of studies ${ }^{9-11}$ evaluated the apical extrusion potential of WOG. Before the introduction of these instruments to the clinical practice, it is important to test the novel systems in vitro and compare the results with those of well-studied file systems. Decreasing the amount of apically extruded debris is one of the needs to be met by the characteristics of the file systems in order to improve the apical healing process and to prevent flare-ups and postoperative pain. ${ }^{5}$ Therefore, the present study evaluated the extrusion potential of the abovementioned file systems.

Only a limited number of studies have evaluated debris extrusion from the mandibular molars, which were instrumented with reciprocating files as in the present study. ${ }^{16,17}$ In the previous studies, the mean weight of the extruded debris with the OS file was reported between 0.00018 and 0.00069 g. ${ }^{3,17,18}$ This amount was reported to be between 0.00019 and 0.00085 $\mathrm{g}$ for PTN. ${ }^{2,19-23}$ These values are relatively lower compared to the results obtained in our study. This finding might have occured primarily due to the use of single-rooted teeth in the extrusion studies. $^{2-4,9,19,22}$ Using single-rooted teeth might result in a lesser amount of debris because of the simple and larger roots in regards to the canal anatomy. ${ }^{16}$ This could explain the larger amount of apically extruded debris in the current study, especially in the OS and PTN groups. The amount and the type of irrigant could also affect the weight of extruded debris. ${ }^{24}$ Considering the reciprocating systems $\mathrm{WO}$ and $\mathrm{R}$, the amount of extruded debris is consistent with the amounts reported in the previous studies..$^{9,25}$ A significantly more amount of debris was extruded by the WO instruments compared to the amount extruded with the $\mathrm{R}$ and PTN instruments. However, previous studies ${ }^{3,4,21}$ have demonstrated no significant differences between WO and R. Conflicting results have been reported when the WO and PTN systems were compared. Pawar et al. ${ }^{19}$ reported that WO resulted in the extrusion of a significantly more amount of debris compared to PTN similar to the result of the present study. In contrast, Ustun et $a l^{2}$ reported a significantly more amount of apically extruded debris with PTN compared to WO, whereas some studies $^{20,21,23}$ could not detect any significant difference between these instruments.

In the present study, a significant difference was not detected between the RB and R groups. A significantly less amount of extruded debris was obtained in the RB group compared to the OS and WOG groups. Uslu et al. ${ }^{12}$ reported that Hyflex EDM (HEDM; Coltene/Whaledent, Altstaatten, Switzerland), extruded less debris compared to RB by its continuous rotary movements although there were no significant differences between these two systems. In the present study, RB extruded less debris than OS, continuous rotary system, which used as control. The differences between the results can be attributed to different design characteristics and raw materials of the continuous rotary file systems. Karataş et al. ${ }^{9}$ reported that the WO group yielded a significantly more amount of extruded debris compared to the WOG group. However, in the present study, there was no difference between these two systems in terms of the amounts of apical extrusion. Dincer et al. ${ }^{11}$ reported that PTN files produced a higher amount of debris compared to WOG. These results are not consistent with the current study. As mentioned earlier, different parameters such as the tooth type, the amount of irrigant used, the last file used for instrumentation could affect the results of the studies.

The extrusion set-up has few limitations including the absence of tissues mimicking the periodontal ligament. Today, there are some methods available to mimic periapical resistance such as agar jel ${ }^{26}$ and floral foam. ${ }^{27}$ However, while the foam used in simulating the periapical pressure may absorb some debris, ${ }^{28}$ the agar jel 
does not simulate periapical resistance sufficiently compared to the resistance of the periapical tissues. ${ }^{29}$ There are no studies available in the literature, comparing different set-ups regarding the apical extrusion. In the future, the effect of different set-ups on the apically extruded debris might be investigated. The set-up in the present study was beneficial for comparing the amount of extruded debris using different NiTi systems. ${ }^{10,30}$

\section{CONCLUSIONS}

The null hypothesis proposed in this study was rejected under the experimental conditions of this in vitro study. The RB and WOG file systems produced amounts of extruded debris similar to the amounts obtained by using well-studied file systems. RB and WOG showed different results in terms of debris extrusion. However, both file systems were similar to their precursors in terms of this parameter and were safe for use in molar root canals.

\section{ACKNOWLEDGEMENT}

The authors declare that they have no conflict of interest.

This study was supported by the Scientific Research Projects Coordination Unit of the University (THD-2017-15353).

\section{CONFLICT OF INTEREST}

None

\section{Farklı Nikel-Titanyum Sistemlerinin Apikal Debris Ekstrüzyonu Açısından Karşılaştırılması $\ddot{O} Z$}

Amaç: Bu çalışmanın amacl, farklı nikel titanyum ĕge sistemlerini apikalden taşan debris miktarı açısından değerlendirmektir. Gereç ve Yöntemler: Bu çalışmada mesial köklerinde iki ayr kanal ve apikal foramene sahip toplam 30 adet mandibular molar diş seçildi. Kök kanalları $(n=10)$ aşağıldaki altı eğe sistemine göre rastgele ayrlmıştır: ProTaper Next (PTN), WaveOne (WO), WaveOne Gold (WOG), One Shape (OS), Reciproc $(R)$ ve Reciproc Blue (RB). Instrümantasyon sırasında ekstrüde edilmiş debrisler önceden boş ă̆ırlıkları ölçülmüş eppendorf tüplerinde toplandı ve sonra irrigantı buharlaştırmak için beş günlük bir süre boyunca $70^{\circ} \mathrm{C}^{\prime}$ de bir inkübatörde saklandr. Inkübasyon sürecinden sonra, eppendorf tüpleri tekrar tartıldı. Bu iki ölçüm arasındaki fark hesaplandı. Veriler istatistiksel olarak analiz edildi ve anlamlılık düzeyi p<0,05 olarak belirlendi. Bulgular: $R, W O$ ile karşılaştırıldığında daha az debris taşmasına sebep oldu. $R$ ve PTN eğeleri, OS eğelere göre anlaml derecede daha az debris taşımına sebep oldu ( $p$ $<0,05)$. RB ve WO gruplarında apikalden taşan debris miktarl anlamlı ölçüde farklı değildi ancak $R B$ WOG ve OS'den daha az debris taşmasina sebep oldu ( $p<0,05)$. Sonuçlar: Bütün ĕge sistemleri apikalden debris taşırmiştır.

Anahtar Kelimeler: Endodonti, kök kanal hazırlama, kök kanal tedavisi.

\section{REFERENCES}

1. Peters OA. Current challenges and concepts in the preparation of root canal systems: a review. J Endod 2004;30:559-567.

2. Ustun Y, Canakci BC, Dincer AN, Er O, Duzgun S. Evaluation of apically extruded debris associated with several Ni-Ti systems. Int Endod J 2015;48:701-704.

3. Nayak G, Singh I, Shetty S, Dahiya S. Evaluation of apical extrusion of debris and irrigant using two new reciprocating and one continuous rotation single file systems. J Dent (Tehran) 2014;11:302-309.

4. Uzun I, Guler B, Ozyurek T, Tunc T. Apical extrusion of debris using reciprocating files and rotary instrumentation systems. Niger $\mathbf{J}$ Clin Pract 2016;19:71-75.

5. Seltzer S, Naidorf IJ. Flare-ups in endodontics: I. Etiological factors. J Endod 1985;11:472-478.

6. De-Deus G, Silva EJ, Vieira VT, Belladonna FG, Elias CN, Plotino G, Grande NM. Blue Thermomechanical Treatment Optimizes Fatigue Resistance and Flexibility of the Reciproc Files. J Endod 2017;43:462-466.

7. Van der Vyver PJ, Paleker F, Vorster M, de Wet FA. Root Canal Shaping Using Nickel Titanium, MWire, and Gold Wire: A Micro-computed Tomographic Comparative Study of One Shape, ProTaper Next, and WaveOne Gold Instruments in Maxillary First Molars. J Endod 2019;45:62-67.

8. Hieawy A, Haapasalo M, Zhou H, Wang ZJ, Shen Y. Phase Transformation Behavior and Resistance to Bending and Cyclic Fatigue of ProTaper Gold and ProTaper Universal Instruments. J Endod 2015;41:1134-1138.

9. Karatas E, Ersoy I, Gunduz HA, Uygun AD, Kol E, Cakici F. Influence of Instruments Used in Root Canal 
Preparation on Amount of Apically Extruded Debris. Artif Organs 2016;40:774-777.

10. Boijink D, Costa DD, Hoppe CB, Kopper PMP, Grecca FS. Apically Extruded Debris in Curved Root Canals Using the WaveOne Gold Reciprocating and Twisted File Adaptive Systems. J Endod 2018;44:1289-1292.

11. Dincer AN, Guneser MB, Arslan D. Apical extrusion of debris during root canal preparation using a novel nickel-titanium file system: WaveOne gold. J Conserv Dent 2017;20:322-325.

12. Uslu G, Ozyurek T, Yilmaz K, Gundogar M, Plotino G. Apically Extruded Debris during Root Canal Instrumentation with Reciproc Blue, HyFlex EDM, and XP-endo Shaper Nickel-titanium Files. J Endod 2018;44:856-859.

13. Schneider SW. A comparison of canal preparations in straight and curved root canals. Oral Surg Oral Med Oral Pathol 1971;32:271-275.

14. Myers GL, Montgomery S. A comparison of weights of debris extruded apically by conventional filing and Canal Master techniques. J Endod 1991;17:275-279.

15. Tanalp J, Gungor T. Apical extrusion of debris: a literature review of an inherent occurrence during root canal treatment. Int Endod J 2014;47:211-221.

16. De-Deus G, Neves A, Silva EJ, Mendonca TA, Lourenco C, Calixto C, Lima EJ. Apically extruded dentin debris by reciprocating single-file and multi-file rotary system. Clin Oral Investig 2015;19:357-361.

17. Pawar AM, Pawar M, Kfir A, Thakur B, Mutha P, Banga KS. Effect of glide path preparation on apical extrusion of debris in root canals instrumented with three single-file systems: An ex vivo comparative study. J Conserv Dent 2017;20:110-114.

18. Burklein S, Benten S, Schafer E. Quantitative evaluation of apically extruded debris with different single-file systems: Reciproc, F360 and OneShape versus Mtwo. Int Endod J 2014;47:405-409.

19. Pawar AM, Pawar MG, Metzger Z, Kokate SR. The self-adjusting file instrumentation results in less debris extrusion apically when compared to WaveOne and ProTaper NEXT. J Conserv Dent 2015;18:89-93.

20. Cicek E, Akkocan O, Furuncuoglu F. Comparison of apically extruded debris associated with several nickel-titanium systems after determining working length by apex locator. J Conserv Dent 2016;19:68-71.
21. Verma M, Meena N, Kumari RA, Mallandur S, Vikram R, Gowda V. Comparison of apical debris extrusion during root canal preparation using instrumentation techniques with two operating principles: An in vitro study. J Conserv Dent 2017;20:96-99.

22. Topcuoglu HS, Zan R, Akpek F, Topcuoglu G, Ulusan O, Akti A, Duzgun S, Agirnasligil M. Apically extruded debris during root canal preparation using Vortex Blue, K3XF, ProTaper Next and Reciproc instruments. Int Endod J 2016;49:1183-1187.

23. Ozsu D, Karatas E, Arslan H, Topcu MC. Quantitative evaluation of apically extruded debris during root canal instrumentation with ProTaper Universal, ProTaper Next, WaveOne, and selfadjusting file systems. Eur J Dent 2014;8:504-508.

24. Leonardi LE, Atlas DM, Raiden G. Apical extrusion of debris by manual and mechanical instrumentation. Braz Dent J 2007;18:16-19.

25. Lu Y, Chen M, Qiao F, Wu L. Comparison of apical and coronal extrusions using reciprocating and rotary instrumentation systems. BMC Oral Health 2015;15:92.

26. Lu Y, Wang R, Zhang L, Li H, Zheng Q, Zhou X, Huang D. Apically extruded debris and irrigant with two $\mathrm{N}$ iT i systems and hand files when removing root fillings: a laboratory study. Int Endod J 2013;46:1125-1130.

27. Altundasar E, Nagas E, Uyanik O, Serper A. Debris and irrigant extrusion potential of 2 rotary systems and irrigation needles. Oral Surg Oral Med Oral Pathol Oral Radiol Endod 2011;112:31-35.

28. Bürklein S, Schäfer E. Apically extruded debris with reciprocating single-file and full-sequence rotary instrumentation systems. J Endod 2012;38:850-852.

29. Nevares G, Xavier F, Gominho L, Cavalcanti F, Cassimiro M, Romeiro K, Alvares P, Queiroz G, Sobral AP, Gerbi M. Apical extrusion of debris produced during continuous rotating and reciprocating motion. Sci World J 2015

30. Gunes B, Yesildal Yeter K. Effects of Different Glide Path Files on Apical Debris Extrusion in Curved Root Canals. J Endod 2018;44:1191-1194. 